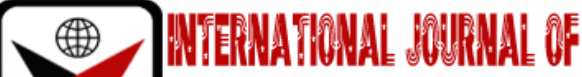

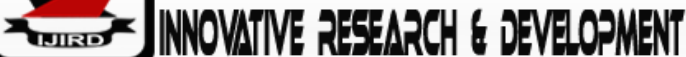

ISSN $2278-0211$ (Online)

\section{The Effect of Persuasive Communication on Increasing Visitors and Income of Affiliate Marketers Area Dki Jakarta, Indonesia}

\begin{tabular}{|c|}
\hline Yoyoh Hereyah \\
Lecturer, Department of Communication Science, \\
Universitas Mercu Buana Jakarta, Indonesia \\
Novianika Hutajulu \\
Lecturer, Department of Communication Science, \\
Universitas Mercu Buana Jakarta, Indonesia \\
\hline
\end{tabular}

\begin{abstract}
:
The digital era is currently giving birth to new phenomena, and one of them is the GIG Economy. Gig Economy is a phenomenon that refers to Affiliate marketers' interest in working as freelancers who are not bound by a contract with the company, and there is no limit to the number of trade portals they can join. They can become part of several online shops both from within the country and abroad. The way business affiliates work is to attract as many visitors as possible to the merchant's website that sells products or services so that transactions occur between them, so good communication skills and persuasion techniques are needed to influence and persuade them to make transactions.

Persuasive communication is now the main thing. The goal of persuasive communication is a change in attitude. Attitude is our tendency towards something, which touches knowledge, motive, and action.

To achieve the research objectives, quantitative research methods are used through questionnaires to 200 respondents to obtain data empirically. The point of view used in this research is the comparative explanatory type case study perspective.

The results of this study also illustrate that there is an effect of persuasive communication on increasing sales. The average states strongly agree with the statements in this table. On average, $45.3 \%$ agreed, and $21.4 \%$ strongly agreed. On the other hand, only a small proportion of $8.0 \%$ expressed disagreement, and $0.2 \%$ strongly disagreed. Research suggests that direct message and treatment of consumers preferably personal even though social media is their communication tool.
\end{abstract}

Keywords: Persuasive communication, visitors, affiliate marketers, freelancers

\section{Background}

The current era of globalization has had many influences. The development of science and technology further encourages the creation of innovations in the use of technological results. According to the Merchant Machine agency, globalization has made Indonesia the country with the fastest-growing e-commerce in the world. Indonesia leads the ranks of these countries with 78\% growth in 2018. Based on iPrice's data, Tokopedia and Bukalapak are Indonesia's most popular electronic commerce sites. Bukalapak gets 116 million monthly visitors, and Tokopedia with 168 million monthly visitors.

Globalization brings many positive and negative impacts based on the phenomena arising from this globalization, such as the emergence of the Gig Economic phenomenon, which has recently become popular. Gig Economy means an economic condition in which there is a shift in company workers' status, who are generally permanent workers into shortterm contract employees, independent workers, or temporary workers. From this condition, the Gig Economy popularized the term freelance worker.

Gig Economy is already developing in Indonesia. The example closest to us is the online transportation driver. Mainly what freelancers need is that they must have special skills as competitive capital. Like when freelancers engage in online electronic commerce, they are required to attract cyber citizens. Here freelancers don't have to have a shop. Freelancers who have marketing skills but don't have the products offered can join in Affiliate Marketing. Not a few freelancers depend on their income every month from this marketing strategy and make it a profession known as an Affiliate Marketer, especially since they can join more than one online business portal without being limited in number.

In Wikipedia, affiliate marketing is a marketing model of other people's products or services where we will get a commission for every sale. Owners who want their products to be sold by other people will usually create an affiliate program. The easiest example is Amazon.com, the largest shopping site globally that allows everyone to participate in marketing hundreds of thousands of products on Amazon as Amazon Associates, one of the oldest affiliate programs in the world (Rianto Aston). 
The main key to running Affiliate Marketing lies in Traffic Generation, which brings traffic or visitors (visitors) who click on the affiliate marketer's affiliate link. Affiliate income is not only measured by how many products they sell. The high number of visitors accessing their links is also taken into account by the size of the revenue they will receive. So that affiliate marketers are competing to make communication as persuasive as possible so that citizens of the virtual world want to access the links offered.

Betting has (1973: 10) says Persuasion is an attempt to influence a person's thoughts and actions, or the activity relationship between the speaker and listener where the speaker tries to control the listener's behavior through hearing and sight an intermediary. Meanwhile, persuasive communication is a communication process that aims to influence others' thoughts and opinions to adjust the communicator or speaker's views and desires.

In this brief explanation, the researcher wants to know the effect of persuasive communication in business affiliates to increase the income of affiliate marketers. For this reason, the researchers took the title of this study is "The Effect of Persuasive Communication on the Increase in the Number of Visitors and Income of the DKI Jakarta Area Affiliate Marketers."

\section{Literature Review}

\subsection{Previous Similar Research Review}

Discussing persuasive communication has also been conducted by some previous research. Some of the studies used as references are; Aditya Wardhana (2015), Vetri Selvi M, et al. (2018), Traci L. Austin et al. (2018), Zia ul Haq (2012), Debby Ariesta Sidabutar (2016), Tina Rakhmatin (2017), Theresia Pradiani (2017), Grzegorz Mazurek1, Ph.D. et al. (2011), Muhammat Rasid Ridho (2013), Mochamad Malik Akbar Rohandi (2017), Desy Natalia (2017), NA Pradipto, Sukarelawati et al. (2017), Arief Andy Soebrot et al. (2010), Martua Eliakim Tambunan (2016), Maria Fitriah (2015).

The similarity of this research with research conducted by researchers is the same as discussing persuasive communication to improve or succeed the communicator's goals. This journal examines how persuasive communication plays an important role. The difference is, none of these journals have discussed the effect of compelling communication on the number of visitors and the increase in income of affiliate marketers.

\subsection{Persuasive Communication}

Persuasion has become an alternative that is widely used in communication. The term persuasion comes from the Latin word influence, whose verb is persuadere, which means to persuade, invite, or seduce. Hovland, Janis, and Kelly (in Tan, 1981: 93) define persuasive communication as the process by which an individual (communicator) transmits stimuli or message (usually verbal) to modify the behavior of the other individuals (the audience). Persuasive communication is a process in which a person (communicator) delivers stimuli or messages (usually a verbal symbol) to influence the behavior of others (communicants). Hovland, Janis, and Kelley (in Tan, 1981: 95) suggests a persuasive communication model called the Instrumental Theory of Persuasion model.

Persuasion can be done rationally and emotionally, usually touching aspects of affection, namely things related to emotional life, usually dynamic elements of attachment, namely associated with a person's personal life. Through expressive means, a person's sympathy and empathy can be aroused (Herdiyan Maulana, Gumgum Gumelar, Psychology of Communication and Persuasion, Jakarta: Akademia Permata 2013, p. 7).

The goal of persuasive communication is a change in attitude. Attitude is our tendency towards something. Philosophy is whether we like or dislike something. In the compelling communication process carried out by affiliate marketers, consumers are positioned as communicants expected to experience changes in attitude following persuasion goals. In this study, the intervening factors studied were based on the Instrumental Theory of Persuasion model from Hovland, Janis, and Kelley (in Tan, 1981: 95), which states that the intervening process consists of attention, understanding, and acceptance.

\subsubsection{Dependent or Dependent Factors Include}

Attention, namely the organism's attention to the message, the message's source, or the way the message is conveyed. Comprehension, which is concerned with examining the meaning or message expressed. Acceptance, which is related to the issue of acceptance or the purpose meant. Business Affiliates According to Buana (2011), "Business affiliation is a marketing process on the internet to sell other people's products. If later there is a sale from this marketing effort, the affiliate marketer (the person who runs the affiliate business) will get a commission whose amount is determined by the product owner (merchant) ". In this affiliated need is trust, goodwill, affection, love, and sympathetic empathy manifested in a friendly, social, pleasant, loving, and trusting attitude, and being kind (Martaniah, 1984).

According to McClelland, the aspects of the need for affiliation are: (1) Prefer to be with other people rather than alone (2) Frequently interacting with other people; (3) Want to be liked and accepted by others (4) Pleasing others (5) Show and maintain a loyal attitude towards people around (6) Seek approval and agreement from others (Rupawanti, 2008).

Business affiliate's work is almost the same as brokers or intermediaries in the offline world, namely how fellows bring as many visitors as possible to merchant websites that sell products or services. When a website visitor purchases a merchant's product or service, the affiliate will get a merchant's commission. The website owner or merchant will know that the visitor came based on an affiliate reference because before marketing the merchant's product, the affiliate will be given a special link or commonly known as an affiliate link or web replica. The affiliate link will notify the system on the merchant's website if there is a sale and who the affiliate has been successful in referring. People who make money this 
way are called 'affiliate marketers' or affiliates. Some of the popular affiliate program providers are eBay, Amazon.com, Linkshare, and Commission Junction.

\section{Method}

\subsection{Research Flow Chart}

\subsubsection{Definition of Persuasion}

Ronald L. Applbaum and Karl W.E. Anatol (1974: 12) defines Persuasion as a "complex process of communication by which one individual or group a specific response from another individual or group" (Persuasion is a complex communication process when individuals or groups express messages (intentionally or unintentionally) through verbal and non-verbal ways to get certain responses from individuals or other groups). So, the assumptions that appear as well as the main hypothesis are:

There is a persuasive communication effect on the increase in the number of visitors and income of affiliate marketers in the DKI Jakarta area sribulancer.com.

\subsection{Fishbone Research Diagram}

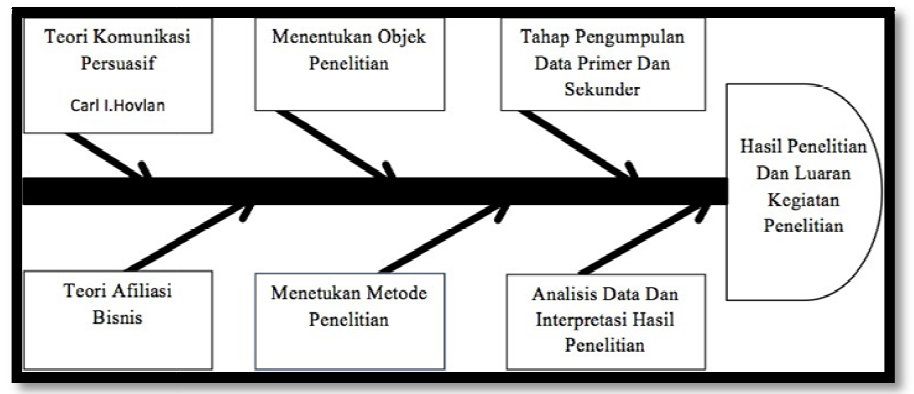

Figure 1: Positivistic Paradigm

\subsubsection{Deductive Logic}

The case study perspective is explanatory

\subsubsection{Quantitative Method}

- The data collection technique used a closed questionnaire

- The data analysis technique used the SPSS program

- Non-probability sampling technique based on strata or stratified samples

- The sampling population is the affiliate marketers in the DKI Jakarta area

\section{Research Design}

The sampling population of this study was DKI Area affiliate marketers, and to determine the number of research samples, the Slovin formula was used as follows:

Formula Description

$$
n=\frac{N}{1+N e^{2}}
$$

$\mathrm{n}=$ number of samples

$\mathrm{N}=$ number of population

$\mathrm{e}=$ leeway inaccuracy due to tolerable sampling errors, the percentage set is $10 \%=0.1$

The sampling technique used was a non-probability sampling technique based on strata or stratified samples. For sample size allocation, proportional allocation / comparative allocation is used. A Likert scale technique is used (Sugiyono, 2014: 132). Types of data used are primary data and secondary data, data collection techniques using closed questionnaires, data analysis techniques using the SPSS (Statistical Program for Social Science) program.

To measure the degree of relationship between variables used Pearson Product Moment Correlation. The hypothesis was tested by a t-test at a significant level ( $\alpha$ ) 0.05 in two directions. Then a decision is made about whether the null hypothesis is accepted or rejected (Ho) or the working hypothesis (Ha) by comparing count with t-table with the following limitations:

If the count $\leq$ table or a significant value (sig.) $\geq$ is 0.05 , Ho is accepted, and Ha is rejected.

If the count $\geq$ table or a significant value (sig.) $\leq$ is 0.05 , Ho is rejected, and Ha is accepted.

To test the validity of the data, the validity and reliability tests were used as follows (Sugiyono, p. 230):

Validity test using correlation techniques, by comparing the results of the correlation rcount with rtable as follows:

If the $t$ count is less than the table, then the statement item is invalid.

If the t count is greater than the table, then the statement item is valid.

Reliability test using Cronbach's Alpha formula, which is interpreted as a positive relationship between statements. The basis for making the reliability test decision, as explained by Sugiyono (2013: 230), is as follows: 
- If $\alpha$ is positive and $\alpha$ is greater than the $\mathrm{r}$ table, then the instrument is reliable.

- If $\alpha$ is positive and $\alpha$ is smaller than the $r$ table, then the instrument is not reliable.

- If $\alpha$ is negative and $\alpha$ is greater than the $\mathrm{r}$ table, then the instrument is not reliable.

- If $\alpha$ is negative and $\alpha$ is smaller than the r table, then the instrument is not reliable.

\subsection{Research Results and Discussion}

The majority of respondents (73.3\%) who are affiliate marketers at Beliviva.com stated that information through verbal communication directly increases consumer knowledge about Viva products' existence. Even more than 25 percent $(27.7 \%)$ also strongly agree with this statement. Only a small proportion disagreed $(4.0 \%)$, and absolutely no one answered strongly disagree $(0.0 \%)$.

The majority of respondents $(74.7 \%)$ who are affiliate marketers at Beliviva.com stated that information through verbal communication indirectly increases consumer knowledge about Viva products. Even 6.7 percent of them strongly agree with this statement. Only a small proportion of disagreed (18.7\%) and absolutely no one answered strongly disagree $(0.0 \%)$.

The majority of respondents (72.0\%) who are affiliate marketers at Beliviva.com stated that information through personal messages on the WhatsApp application increases consumer knowledge about Viva products. Even 26.7 percent of them strongly agree with this statement. Only a small proportion disagreed (1.3\%), and absolutely no one answered strongly disagree $(0.0 \%)$.

The majority of respondents (72.2\%) who are affiliate marketers at Beliviva.com stated that information through broadcast messages on the WhatsApp application increases consumer knowledge about Viva products. Even 14.7 percent of them strongly agree with this statement. Only a small proportion of disagreed (13.3\%) and absolutely no one answered strongly disagree $(0.0 \%)$.

The majority of respondents $(74.7 \%)$ who are affiliate marketers at Beliviva.com stated that information through publications on personal social media accounts increases consumer knowledge about Viva products. Even 21.3 percent of them strongly agree with this statement. Only a small proportion disagreed (4.0\%), and absolutely no one answered strongly disagree $(0.0 \%)$.

The majority of respondents (69.3\%) who are affiliate marketers at Beliviva.com stated that information through direct messages on personal social media accounts effectively increases consumer knowledge about Viva products. Even 13.3 percent of them strongly agree with this statement. Only a small proportion of disagreed $(17.3 \%)$ and absolutely no one answered strongly disagree $(0.0 \%)$.

The majority of respondents (69.3\%) who are affiliate marketers at Beliviva.com stated that information through direct verbal communication increases consumer knowledge about Viva product explanations. Even 25.3 percent of them strongly agree with this statement. Only a small proportion disagreed (5.3\%), and absolutely no one answered strongly disagree $(0.0 \%)$.

The majority of respondents $(70.7 \%)$ who are affiliate marketers at Beliviva.com stated that information through verbal communication indirectly increases consumer knowledge about Viva product explanations. Even 8.0 percent of them strongly agree with this statement. On the other hand, only a small proportion disagreed (21.3\%), and absolutely no one gave an answer strongly disagree $(0.0 \%)$.

The majority of respondents $(76.0 \%)$ who are affiliate marketers at Beliviva.com stated that information through personal messages on the WhatsApp application increases consumer knowledge about Viva products. Even 21.3 percent of them strongly agree with this statement. On the contrary, only a small proportion disagreed $(2.7 \%)$, and absolutely no one gave an answer strongly disagree $(0.0 \%)$.

The majority of respondents $(84.0 \%)$ who are affiliate marketers at Beliviva.com stated that information via broadcast messages on the WhatsApp application increases consumer knowledge about Viva product explanations. Even 9.3 percent of them strongly agree with this statement. On the contrary, only a small proportion disagreed (6.7\%), and absolutely no one gave an answer strongly disagree $(0.0 \%)$.

The majority of respondents (76.0\%) who are affiliate marketers at Beliviva.com stated that information through publications on personal social media accounts increases consumer knowledge about Viva product explanations. Even 22.7 percent of them strongly agree with this statement. On the contrary, only a small proportion disagreed (1.3\%), and absolutely no one gave an answer strongly disagree $(0.0 \%)$.

The majority of respondents (78.7\%) who are affiliate marketers at Beliviva.com stated that information through direct messages on personal social media accounts increases consumer knowledge about Viva product explanations. Even 24.0 percent of them strongly agree with this statement. On the contrary, only a small proportion disagreed (4.0\%), and absolutely no one gave an answer strongly disagree $(0.0 \%)$.

The majority of respondents $(72.0 \%)$ who are affiliate marketers at Beliviva.com stated that information through direct verbal communication increases consumer knowledge about Viva products' advantages. Even 24.0 percent of them strongly agree with this statement. On the contrary, only a small proportion disagreed (4.0\%), and absolutely no one gave an answer strongly disagree $(0.0 \%)$.

A majority of respondents (77.3\%) who are affiliate marketers at Beliviva.com state that information through verbal communication indirectly increases consumer knowledge about Viva products' advantages. Even 8.0 percent of them strongly agree with this statement. On the other hand, only a small proportion disagreed (14.7\%), and absolutely no one gave an answer strongly disagree $(0.0 \%)$.

The majority of respondents (82.7\%) who are affiliate marketers at Beliviva.com stated that information through personal messages on the WhatsApp application increases consumer knowledge about Viva products' advantages. Even 
16.0 percent of them strongly agree with this statement. On the contrary, only a small proportion disagreed (1.3\%), and absolutely no one gave an answer strongly disagree $(0.0 \%)$.

The majority of respondents (77.3\%) who are affiliate marketers at Beliviva.com stated that information via broadcast messages on the WhatsApp application adds to consumer knowledge about Viva products' advantages. Even 12.0 percent of them strongly agree with this statement. On the other hand, only a small proportion disagreed (10.7\%), and absolutely no one gave an answer strongly disagree $(0.0 \%)$.

The majority of respondents (78.7\%) who are affiliate marketers at Beliviva.com stated that information through publications on personal social media accounts increases consumer knowledge about Viva products' advantages. Even 21.3 percent of them strongly agree with this statement. On the other hand, none of them gave disagreement $(0.0 \%)$ and strongly disagreed $(0.0 \%)$ answers.

The majority of respondents $(73.3 \%)$ who are affiliate marketers at Beliviva.com stated that information through direct messages on personal social media accounts increases consumer knowledge about Viva products' advantages. Even 12.0 percent of them strongly agree with the statement. On the other hand, only a small proportion disagreed (14.7\%), and absolutely no one gave an answer strongly disagree $(0.0 \%)$.

It can be seen from the responses of respondents in this study. The questions in this table are answered that there is an effect of persuasive cognitive-communication on increasing sales. Specifically, this can be seen in respondents' average response to the study that $56.3 \%$ of them agree and $16.1 \%$ of them strongly agree. On the other hand, only a small portion of $8.8 \%$ gave disagreement and completely disagreed $(0.0 \%)$.

\section{Discussion}

This study aims to determine the effect of persuasive communication from affiliate marketers on increased sales of viva products on Beliviva.com. Affiliate marketers also obtained information about the existence of Beliviva.com from social media.

The results of research conducted on variables regarding the influence of persuasive communication of affiliate marketers on the increase in sales of Viva products on Beliviva.com (survey of cognitive, affective, and conative application) are stated to have met the validity test requirements. Based on the Pearson validity test results for the X1 dimension, all questionnaire items can be categorized as valid. All $r$ count is more than $r$ table $5 \%$ with $N$ of 75 . Then, the significance value of each questionnaire item is 0.000 . Thus, each questionnaire item on the X1 dimension can be included in the data analysis process. Descriptive statistics in this study can provide an overview of the characteristics of the research object. This general description can be seen from the average response of research respondents to each questionnaire item in this study. From the respondents' responses in this study, they answered that there was an effect of cognitive persuasive communication on increasing sales. Specifically, this can be seen in respondents' average response to the study that $56.3 \%$ of them agree and $16.1 \%$ of them strongly agree. On the other hand, only a small proportion of $8.8 \%$ gave disagreement and completely disagreed $(0.0 \%)$.

\subsection{Conclusions and Suggestions}

The results of this study also illustrate that there is persuasive cognitive side communication on increasing sales. The average states strongly agree with the statements in this table. On average, $45.3 \%$ agreed, and $21.4 \%$ strongly agreed. Based on the research results, the advice that can be given to Beliviva.com is that it is better to maintain and increase knowledge about persuasive communication to affiliate marketers. With the increase in effective communication skills, it is hoped that in line with the rise in these affiliates' income.

\section{References}

i. Pramelani. (2018). Efek Kognitif, Afektif dan Behavioral pada Kampanye Registrasi Prabayar Seluler. Komunikasi, 9(1), 1-7.http://ejournal.bsi.ac.id/ejurnal/index.php/jkom

ii. Husein Ammarie, Rivky. Nurfebiaraning, Sylvie. (2018). Pengaruh Iklan Pop-Up Bukalapak Versi Pahlawan Pada Youtube Terhadap Sikap Khalayak http://jurnal.unpad.ac.id/manajemen-komunikasi/article/view/12871

iii. Wardhana. (2015). Strategi Digital Marketing Dan Implikasinya Pada Keunggulan Bersaing Ukm Di Indonesia https://www.researchgate.net/publication/327069950_strategi_digital_marketing_dan_implikasinya_pada_keu nggulan_bersaing_ukm_di_indonesia

iv. Suresh V , Vetri Selvi M, Maran K ARShanmuga Priya. (2018). A study on impact of an affiliate marketing in ebusiness for consumers' perspective http://www.enggjournals.com/ijet/docs/IJET18-10-02-050.pdf

v. Traci L. Austin, Lindsay C. Clark. (2018). Practical Persuasive Communication: The Evolving Attitudes of the iGeneration Student http://www.ejbest.org

vi. Sidabutar, Diana Ariesta. (2016). Komunikasi Persuasif Dan Minat Menjadi Consultant (Studi Korelasional Pengaruh Komunikasi Persuasif Upline Pride BN Terhadap Minat Menjadi Consultant Pada Calon Consultant Oriflame di Kota Medan)http://repositori.usu.ac.id/handle/123456789/3194

vii. Rakmatin, Tina. (2017). Pengaruh Komunikasi Persuasif Personal Sales Terhadap Keputusan Pembelian Produk Al-Quran Miracle The Reference E-Pen https://ojs.unikom.ac.id/index.php/common/article/view/248

viii. Pradipto,Na. Sukarelawati. Kusumadinata, AA. (2017). Pengaruh Komunikasi Persuasif Dalam Meningkatkan Kesadaran Solidaritas Anggota Scooter Mods Bogor Indonesia https://ojs.unida.ac.id/index.php/JK/article/view/915

ix. Tambunan, Martua Eliakim. (2016). Determinan Intensitas Transaksi Afiliasi pada 